\title{
Uji Total Escherichia coli pada Susu Sapi Segar di Koperasi Peternak Sapi Perah (KPSP) Karyo Ngremboko Kecamatan Purwoharjo Kabupaten Banyuwangi
}

\author{
(TOTAL TEST OF Escherichia coli ON FRESH COW MILK AT DAIRY FARMER \\ COOPERATIVE (KPSP) KARYO NGREMBOKO PURWOHARJO BANYUWANGI)
}

\author{
Adhitya Yhoga Pradika ${ }^{1 *}$, Sri Chusniati², Muhammad Thohawi Elziyad Purnama ${ }^{3}$, \\ Mustofa Helmi Effendi ${ }^{4}$, Aditya Yudhana ${ }^{5}$, Prima Ayu Wibawati ${ }^{4}$ \\ ${ }^{1}$ Bachelor of Veterinary Medicine, \\ ${ }^{2}$ Department of Veterinary Microbiology, \\ ${ }^{3}$ Department of Veterinary Anatomy, \\ ${ }^{4}$ Department of Veterinary Public Health, \\ ${ }^{5}$ Department of Veterinary Parasitology, \\ Faculty of Veterinary Medicine, Universitas Airlangga, \\ UNAIR C-Campus Mulyorejo, Surabaya, Jawa Timur, Indonesia, 60115 \\ Telp. (031)5993016, Fax. (031)5993015 \\ *Corresponding author: adhitya.yhoga.p-2014@fkh.unair.ac.id
}

\begin{abstract}
Abstrak
Penelitian ini bertujuan untuk mengukur kualitas susu sapi segar yang disetorkan oleh peternak ke Koperasi dan kemudian dihitung jumlah bakteri Escherichia coli yang selanjutnya dibandingkan dengan SNI. Pengambilan sampel dilakukan pada saat peternak mengantarkan susu sapi segar ke koperasi. Sampel yang diambil adalah susu yang ada di dalam milk can yang diambil dengan pipet steril dan juga karet penghisap. Sampel selanjutnya disimpan di dalam botol steril dan dibawa dengan menggunakan coolbox dilengkapi ice gel beku, selanjutnya dilakukan pengujian di Laboratorium. Selanjutnya dilakukan penanaman pada media Lauryl Tryptose Broth (LTB), Escherichia coli Broth (ECB), Levine Eosin Methylen Blue Agar (L-EMBA) dan dilakukan uji biokimia Indole, Methyl Red, Voges Proskauer, Citrate (IMViC) selanjutnya dilakukan pendugaan jumlah bakteri dengan menggunakan Most Probable Number (MPN). Hasil penelitian didapatkan bakteri Escherichia coli yang melebihi standart SNI > 3 APM/g yaitu 5 dari 16 sampel atau 31,25\%. Hasil perhitungan berdasarkan MPN, sampel 7 menghasilkan angka 3APM/g, sampel 9 menghasilkan angka 3,6 APM/g, sampel 10 menghasilkan angka 23 APM/g, sampel 13 menghasilkan angka 7,4 APM/g dan sampel 14 menghasilkan angka 3,6 APM/g.
\end{abstract}

Kata kunci: susu segar, Escherichia coli, MPN

\section{Abstract}

This study aims to measure the quality of fresh cow's milk deposited by farmers to the cooperative and then count the number of Escherichia coli bacteria which are then compared with SNI. Sampling is carried out when farmers deliver fresh cow's milk to the farmer cooperative. The samples taken were milk in milk can which was taken with sterile pipette and also the suction rubber. The next sample is stored in a sterile bottle and brought by coolbox frozen ice gel, then tested in the laboratory. Furthermore, planting on Lauryl Tryptose Broth (LTB), Escherichia coli Broth (ECB), Levine Eosin Methylen Blue Agar (L-EMBA) and biochemical test of Indole, Methyl Red, Voges Proskauer, Citrate (IMViC) using the Most Probable Number (MPN). The result showed that Escherichia coli bacteria exceeded the standard of SNI > 3 APM/ml 5 of 16 samples or 31,25\%. The result of calculation based on MPN, sample 7 of $3 \mathrm{APM} / \mathrm{ml}$, sample 9 is 3,6 APM/ml, sample 10 is 23 APM/ml, sample 13 is 7,4 APM/ml and sample 14 is 3,6 APM/ml. 


\section{PENDAHULUAN}

Susu segar adalah susu hasil pemerahan dari ternak sapi perah yang kandungan alaminya tidak ditambah maupun dikurangi dan diperoleh dengan cara pemerahan yang bersih dan benar (Standar Nasional Indonesia, 2011). Susu yang masih di dalam kelenjar susu dapat dikatakan steril, tetapi setelah keluar dari ambing dapat terjadi kontaminasi yang berasal dari berbagai sumber yaitu dari ambing sapi, tubuh sapi, debu di udara, peralatan yang kotor dan manusia yang melakukan pemerahan (Yusuf, 2011).

Kontaminan susu pada dasarnya bukan hanya berasal dari debu di udara, bakteri juga berperan pada proses kontaminasi susu. Bakteri yang biasa terdapat dalam susu adalah Streptococcus lactis, Aerobacter aerogenes, Lactobacillus casei, dan juga Escherichia coli (Jawetz et al., 2001).

Susu merupakan makanan yang berpotensi sebagai media penyebaran bakteri (Yusuf, 2011). Salah satu indikasi susu terkontaminasi yaiitu adanya bakteri Escherichia coli yang mencemari susu melebihi batas cemaran mikroba yang ditetapkan oleh Badan Standarisasi Nasional. Badan Standarisasi Nasional menetapkan batas maksimum cemaran mikroba dalam susu yaitu < 3 APM/ml (SNI $7388: 2009)$.

Escherichia coli merupakan salah satu bakteri penyebab kontaminan pada susu. Escherichia coli termasuk bakteri yang dapat menyebabkan diare (Fikri dkk., 2018). Pemerintah sudah menetapkan batas maksimum cemaran pada susu segar supaya aman dikonsumsi oleh masyarakat, yaitu Total Plate Count (TPC) 1x106CFU/ml dan untuk Most Probable Number (MPN) $<3$ APM/ml (SNI 7388, 2009).

Jumlah populasi sapi perah di Kabupaten Banyuwangi pada tahun 2017 adalah 822 ekor. Kecamatan Purwoharjo menjadi kecamatan yang mempunyai populasi sapi perah terbanyak yakni 296 ekor sapi perah (Dinas Peternakan Provinsi Jawa Timur, 2017). Koperasi Peternak Sapi Perah (KPSP) Karyo Ngremboko menjadi wadah peternak di wilayah Purwoharjo untuk mendistribusikan susu.
Penelitian ini bertujuan untuk mengukur jumlah pencemaran bakteri Escherichia coli pada susu sapi segar peternak yang tergabung di Koperasi Peternak Sapi Perah (KPSP) Karyo Ngremboko dibandingkan dengan batas maksimum cemaran bakteri dalam pangan sesuai ketetapan Badan Standarisasi Nasional tahun 2009.

\section{METODE PENELITIAN}

Penelitian ini dilaksanakan di Laboratorium Unit Pelaksana Teknis (UPT) Pengujian Mutu dan Pengembangan Produk Kelautan dan Perikanan (PMP2KP). Penelitian ini dilaksanakan pada bulan Februari 2017. Pengambilan sampel dilakukan di Koperasi Peternak Sapi Perah (KPSP) Karyo Ngremboko Kecamatan Purwoharjo, Banyuwangi.

Peralatan yang digunakan dalam penelitian ini antara lain, botol schott, cawan petri, tabung reaksi, rak tabung reaksi, tabung media, gelas ukur, pipet, tabung durham, jarum inokulasi (ose), spatula kaca, stomacher (Barnstead International ${ }^{\circledR}$ ), pembakar Bunsen, timbangan, inkubator $\left(\right.$ Binder $\left.^{\circledR}\right)$, Waterbath $\left(\right.$ Techne $\left.^{\circledR}\right)$, autoclave dan sarung tangan.

Sampel yang digunakan pada penelitian ini yaitu 16 sampel susu sapi segar yang berada di dalam milk can peternak sebelum diserahkan pada pihak KPSP Karyo Ngremboko. Sampel yang diambil sebanyak 16 sampel masingmasing $50 \mathrm{ml}$. Pengambilan sampel dibagi 3 periode, tiap periode sebanyak 6 sampel dan disimpan pada cool box dengan temperatur $10^{\circ} \mathrm{C}$ untuk dibawa menuju laboratorium PMP2KP. Pengambilan sampel dengan non probability sampling teknik sampling jenuh yang mana sampel diambil keseluruhan tanpa ada peluang.

Pengujian melalui uji pendugaan coliform, uji pendugaan faecalcoliform, uji penegasan, dan uji biokima. Uji biokimia meliputi : Uji produksi indole (I), Ujivoges proskauer (VP), Uji methyl red (MR), dan Uji sitrat (C) (SNI, 2015). Isolasidan Identifikasi bakteri Escherichia coli dalam penelitian ini mengacu pada SNI 012332.1-2015 cara uji mikrobiologi. Escherichia coli adalah bakteri coliform yang termasuk 
kedalam faecal coliform sehingga perlu dilakukan uji sederhana dengan penanaman ke media LTB dan ECB.

Sampel yang diambil diuji dengan metode Most Probable Number (MPN) untuk menghitung jumlah bakteri Escherichia coli pada susu sapi segar yang diambil dari peternak sapi perah KPSP Karyo Ngremboko. Hasil pengujian dicocokkan dengan tabel pengujian Escherichia coli SNI 2332.1:2015. Data yang diperoleh disajikan secara deskriptif dengan tabel dan gambar serta dilakukan persentase hasil berdasarkan jumlah sampel yang teridentifikasi positif Escherichia coli.

\section{HASIL DAN PEMBAHASAN}

Tahap uji pendugaan koliform dari 16 sampel susu pengenceran pertama (10-1) dari 48 tabung media dinyatakan positif, sedangkan untuk pengenceran kedua (10-2) dari total 48 tabung media terdapat 4 tabung media yang dinyatakan negatif, dan pada pengenceran ketiga (10-3) dari total 48 tabung terdapat 30 tabung media yang dinyatakan negatif. Sampel yang dinyatakan positif terdapat perubahan pada media berupa gas pada tabung media. Sampel yang sudah dinyatakan positif dapat dilanjutkan uji pendugaan menggunakan media ECB. Hasil uji pendugaan koliform disajikan pada tabel 1 .

Pengujian koliform fekal didapatkan hasil positif jika media EC terbentuk gas dan kekeruhan pada tabung. Keseluruhan sampel yang berjumlah 16 menandakan hasil positif koliform fekal. Dari 48 tabung media pada pengenceran pertama (10-1) terdapat 3 tabung media yang dinyatakan negatif, sedangkan pada pengenceran kedua (10-2) dan pengenceran ketiga (10-3) masing-masing terdapat hasil negatif 11 tabung media dan 38 tabung media. Hasil pada uji pendugaan koliform fekal disajikan pada tabel 1.

Pengamatan yang dilakukan pada media EMBA hasil penanaman sampel positif koliform fekal ditemukan dua bentuk koloni berbeda. Koloni pertama berbentuk bulat hitam dan berwarna hijau metalik pada pusat koloni, koloni ini dapat dinyatakan sebagai hasil positif. Koloni kedua berbentuk bulat dan berwarna putih, koloni ini dapat dinyatakan sebagai hasil negatif. Dari keseluruhan sampel satu sampel nomor enam dinyatakan negatif dan tidak dilanjutkan pada tahap uji biokimia Escherichia coli. Hasil pada uji penegasan pada media EMBA disajikan pada tabel 1.

Hasil MPN didapat dari identifikasi hasil positif uji biokimia (IMVIC) pada seri tabung pengenceran dan dicocokkan dengan tabel MPN seri tiga tabung. Hasil uji biokimia yang positif berjumlah 5 sampel dari total 16 sampel. Sampel yang positif uji biokimia yaitu sampel nomor 7 , 9, 10, 13, dan 16. Sampel nomor 7 menghasilkan angka $3 \mathrm{APM} / \mathrm{ml}$, nomor 9 menghasilkan angka 3,6 APM/ml, nomor 10 menghasilkan angka 23 APM/ml, nomor 13 menghasilkan angka 7,4 APM/ml dan nomor 16 menghasilkan angka 3,6 APM $/ \mathrm{ml}$. Selain 5 sampel yang positif pada saat uji biokimia terdapat 11 sampel lain dan keseluruhan menghasilkan angka $<3$ APM/ml. Hasil uji biokimia disajikan pada tabel 2 .

Data yang diperoleh dari uji mikrobiologis pada 16 sampel susu segar yang diperoleh dari peternak sapi perah yang tergabung dalam KPSP Karyo Ngremboko di Kecamatan Purwoharjo menunjukkan bahwa 5 diantaranya melebihi batas maksimum cemaran mikroba yang ditetapkan oleh Badan Standarisasi Nasional 7388 Tahun 2009. Sampel yang menunjukkan nilai < $3 \mathrm{APM} / \mathrm{ml}$ masih belum melebihi batas maksimum cemaran mikroba yang ditetapkan oleh Badan Standarisasi Nasional. Standar ini digunakan untuk kategori produk susu segar yang tidak dipasteurisasi untuk diproses lebih lanjut.

Escherichia coli merupakan salah satu bakteri yang sering mengkontaminasi susu, sebagaimana dibakukan dalam Standar Nasional Indonesia (SNI 7388:2009) diatur bahwa maksimum nilai untuk pemeriksaannya adalah $<3$ APM/ml. Pada penelitian kali ini masih ada susu dari peternak di KPSP Karyo Ngremboko yang melebihi batas maksimum yang ditetapkan Badan Standarisasi Nasional. Hal ini terbukti 5 dari 16 sampel yang di uji menyatakan nilai diatas ambang batas SNI, bahkan sampel nomor 10 menunjukkan nilai $23 \mathrm{APM} / \mathrm{ml}$ yang mana 
jauh dari batas maksimum cemaran yang ditetapkan Badan Standarisasi Nasional.

Tabel 1. Rekapitulasi hasil uji pendugaan koliform dan perubahan pada media dari 16 sampel

\begin{tabular}{cccccc}
\hline Media & Perubahan & $\mathbf{1 0}^{-\mathbf{1}}$ & $\mathbf{1 0}^{-2}$ & $\mathbf{1 0}^{-\mathbf{3}}$ & Total \\
\hline \multirow{2}{*}{ LTB } & ada gas (+) & 48 & 44 & 18 & 110 \\
& tidak ada gas (-) & 0 & 4 & 30 & 34 \\
\hline \multirow{2}{*}{ EC } & gas (+) keruh (+) & 45 & 37 & 10 & 92 \\
& gas (-) keruh (-) & 3 & 7 & 8 & 18 \\
\hline \multirow{2}{*}{ EMBA } & bulat hitam, hijau metalik & 26 & 13 & 3 & 42 \\
& bulat putih & 19 & 24 & 7 & 50 \\
\hline
\end{tabular}

Tabel 2. Rekapitulasi hasil uji biokimia Escherichia coli dan perubahan pada media

Sampel Pengenceran Indole MR VP Citrate

\begin{tabular}{|c|c|c|c|c|c|}
\hline 1 & $10^{-3}$ & - & + & + & + \\
\hline 2 & $10^{-1}$ & + & - & + & + \\
\hline \multirow{2}{*}{3} & $10^{-1}$ & + & + & + & + \\
\hline & $10^{-1}$ & - & + & + & + \\
\hline \multirow{2}{*}{4} & $10^{-2}$ & + & + & + & - \\
\hline & $10^{-3}$ & + & - & + & - \\
\hline \multirow{3}{*}{5} & $10^{-1}$ & + & + & + & + \\
\hline & $10^{-1}$ & + & + & + & + \\
\hline & $10^{-2}$ & - & - & + & + \\
\hline 7 & $10^{-3}$ & + & + & - & - \\
\hline \multirow{3}{*}{8} & $10^{-1}$ & + & - & + & + \\
\hline & $10^{-1}$ & + & + & + & + \\
\hline & $10^{-1}$ & - & + & + & + \\
\hline 9 & $10^{-1}$ & + & + & - & - \\
\hline \multirow{5}{*}{10} & $10^{-1}$ & + & + & - & - \\
\hline & $10^{-1}$ & + & + & - & - \\
\hline & $10^{-1}$ & + & + & - & - \\
\hline & $10^{-2}$ & + & - & + & + \\
\hline & $10^{-2}$ & + & - & - & + \\
\hline \multirow{6}{*}{11} & $10^{-1}$ & + & - & + & + \\
\hline & $10^{-1}$ & + & + & + & + \\
\hline & $10^{-1}$ & - & + & + & + \\
\hline & $10^{-2}$ & - & - & + & + \\
\hline & $10^{-2}$ & + & - & + & + \\
\hline & $10^{-3}$ & + & - & + & + \\
\hline 12 & $10^{-1}$ & - & - & + & + \\
\hline \multirow{3}{*}{13} & $10^{-1}$ & + & + & - & - \\
\hline & $10^{-1}$ & + & - & + & - \\
\hline & $10^{-2}$ & + & + & - & - \\
\hline \multirow{2}{*}{14} & $10^{-1}$ & + & - & - & - \\
\hline & $10^{-1}$ & + & + & + & - \\
\hline \multirow{5}{*}{15} & $10^{-1}$ & + & - & + & - \\
\hline & $10^{-1}$ & + & - & - & - \\
\hline & $10^{-1}$ & + & - & - & + \\
\hline & $10^{-2}$ & + & + & - & + \\
\hline & $10^{-2}$ & + & - & - & + \\
\hline \multirow{6}{*}{16} & $10^{-1}$ & + & + & - & - \\
\hline & $10^{-1}$ & + & - & - & - \\
\hline & $10^{-1}$ & + & + & - & + \\
\hline & $10^{-2}$ & + & - & - & + \\
\hline & $10^{-2}$ & + & - & - & + \\
\hline & $10^{-2}$ & + & + & + & - \\
\hline
\end{tabular}


Menurut Fikri dkk (2017) kejadian kontaminasi Escherichia coli kemungkinan disebabkan karena adanya kontaminasi feses sapi selama penanganan susu pada saat proses pemerahan maupun lama waktu susu di milk can sebelum diserahkan kepada KPSP Karyo Ngremboko. Menurut Bearkley (1986), susu bukan hanya merupakan makanan yang baik bagi manusia tetapi juga bagi bakteri. Kontaminasi yang terjadi pada susu dapat berasal dari badan sapi, lingkungan kandang, peralatan perah, dan juga tangan pemerah yang terinfeksi selama penanganan susu (Sumudhita, 1989).

Faktor yang pertama adalah kebersihan lingkungan kandang dan juga sanitasi peralatan. Setiyanto (1992) menyebutkan kebersihan adalah salah satu faktor yang berperan penting dalam mengurangi tingkat kerusakan susu selama proses penanganan susu karena susu merupakan salah satu bahan pangan yang mudah terkontaminasi oleh bakteri. Berdasarkan pengamatan dilapangan kebersihan kandang sudah terjaga dengan cukup baik akan tetapi ketika pada saat proses pemerasan susu dan juga penanganan susu sebelum diserahkan pada KPSP Karyo Ngremboko masih ada peternak yang terlihat menyalakan rokok. Rokok turut serta menambah resiko susu terkontaminasi melalui udara sekitar, ditambah kondisi tangan yang baru memandikan sapi dan langsung melakukan proses pemerahan juga menjadi faktor tambahan dalam proses kontaminasi susu.

Marlina et al., (2007) menyebutkan kondisi sirkulasi udara di sekitar tempat penanganan susu dipengaruhi banyak faktor, antara lain tetesan air, debu dan pergerakan udara yang diakibatkan manusia maupun angin. Asap rokok yang berhembus ketika susu ditangani dan milk can belum ditutup dengan rapat merupakan hal yang menjadi penyebab susu tercemar. Hal ini terbukti dari 5 sampel peternak positif mengandung bakteri Escherichia coli yang melebihi batas yang ditentukan oleh SNI.

Faktor yang kedua adalah waktu transportasi susu dari peternak ke KPSP Karyo Ngermboko. Perbedaan jumlah Escherichia coli masing- masing peternak kemungkinan dipengaruhi oleh lamanya waktu pemerah menyerahkan susu ke KPSP Karyo Ngremboko. Sesuai penuturan Setiyanto (1992), waktu perjalanan susu harus diusahakan secepat mungkin karena erat berkaitan dengan perkembangan bakteri pada susu. Berdasarkan pengamatan dilapangan pemerah menyerahkan susu dalam waktu yang beragam.

Escherichia coli dapat dijadikan indikator adanya suatu cemaran yang disebabkan feses manusia maupun hewan ke dalam susu. Escherichia coli yang terdapat pada susu segar dikhawatirkan dapat berkembang biak dan menimbulkan gangguan kesehatan bagi masyarakat. Diperlukan adanya penanangan dan pemahaman yang baik dalam penanganan dan pengolahan produk susu yang akan disebarluaskan untuk konsumsi masyarakat. Marlina et al., (2007) juga menyebutkan bahwa bakteri pathogen yang ada dalam susu dapat dijamin keamanannya dengan mengontrol sumber cemaran dan mengontrol sanitasi pada saat penanganan susu.

\section{KESIMPULAN}

Susu sapi segar dari peternak KPSP Karyo Ngremboko Kecamatan Purwoharjo Kabupaten Banyuwangi, terdapat 5 dari 16 sampel yang melebihi batas maksimum cemaran mikroba yang ditetapkan oleh Badan Standarisasi Nasional yaitu $<3$ APM/ml.

\section{UCAPAN TERIMA KASIH}

Terimakasih kepada KPSP (Koperasi Peternak Sapi Perah) Karyo Ngremboko Kecamatan Purwoharjo Kabupaten Banyuwangi yang telah mengijinkan untuk meneliti kualitas susu segar. Terimakasih kepada PMP2KP Dinas Perikanan dan Kelautan Kabupaten Banyuwangi yang telah memberikan sarana dan membantu jalannya penelitian.

\section{DAFTAR PUSTAKA}


Bearkley, R.D. 1986. Mikrobiologi Pengolahan Pangan. Departemen Pendidikan dan Kebudayaan. Direktorat Jenderal Pendidikan Tinggi. Pusat Antar-Universitas Pangan dan Gizi IPB Bogor.

Fikri, F., Hamid, I.S., Purnama, M.T.E. 2017. Uji organoleptis, $\mathrm{pH}$, uji eber dan cemaran bakteri pada karkas yang diisolasi dari kios di Banyuwangi. Jurnal Medik Veteriner, 1(1), 23-27.

Fikri, F., Purnama, M.T.E., Saputro, A.L., Hamid, I.S. 2018. Identifikasi Escherichia coli dan Salmonella spp pada Karkas Sapi di Rumah Potong Hewan di Banyuwangi dan Resistensi Terhadap Antibiotika. Jurnal Sain Veteriner, 36(1), 123-128.

Jawetz, E., Melnick, J., Adelberg, E. 2013. Medical Microbiology. 26th Edition. Mc Graw Hill, p232-235.

Marlina, E.T., Hidayati, A.Y., Juanda, W. 2007. Kualitas Mikroba pada Ruang Penampungan Susu dan Pengaruhnya terhadap Jumlah Bakteri dalam Air Susu. Fakultas Peternakan Universitas Padjajaran. Bandung.
Setiyanto, H. 1992. Mengurangi Kerusakan Susu Segar Selama Pemasaran. Swadaya Majalah Peternakan Indonesia. Jakarta. 81, 24-25.

SNI 2897. 2008. Metode Pengujian Cemaran Mikroba dalam Daging, Telur dan Susu Serta Hasil Olahannya. Badan Standarisasi Nasional Indonesia.

SNI 3141. 2011. Susu Sapi Segar. Badan Standarisasi Nasional Indonesia.

SNI 7388. 2009. Batas Maksimum Cemaran Mikroba dalam Pangan. Badan Standarisasi Nasional Indonesia.

Sumudhita, M.W. 1989. Susu dan Penanganannya. Program Studi Ilmu Produksi Ternak Perah. Fakultas Peternakan Universitas Udayana. Denpasar.

Yusuf, A. 2011. Tingkat Kontaminasi Escherichia coli pada Susu Segar di Kawasan Gunung Perak Kabupaten Sinjai. [Skripsi]. Fakultas Peternakan. Universitas Hasanuddin. Makassar. 